\title{
Publisher Correction to: Challenges and strategies in conducting sexual and reproductive health research among Rohingya refugees in Cox's Bazar, Bangladesh
}

\author{
Rushdia Ahmed ${ }^{1 *}+$ Bachera Aktar $^{1+}$, Nadia Farnaz ${ }^{1 \dagger}$, Pushpita Ray ${ }^{1 \dagger}$, Abdul Awal $^{1+}$, Raafat Hassan $^{1+}$, \\ Sharid Bin Shafique ${ }^{1+}$, Md Tanvir Hasan', Zahidul Quayyum, Mohira Babaeva Jafarovna², Loulou Hassan Kobeissi ${ }^{2}$, \\ Khalid El Tahir ${ }^{3}$, Balwinder Singh Chawla ${ }^{3}$ and Sabina Faiz Rashid ${ }^{1}$
}

\author{
Correction to: Confl Health 14, 83 (2020) \\ https://doi.org/10.1186/s13031-020-00329-2
}

In the publication of the original article [1] an error was introduced during the typesetting process. Due to this: the original publication did not show the correct equal contribution of the author groups.

In this correction article the correct and incorrect information is shown. The original article has been updated.

\section{Incorrect:}

† Rushdia Ahmed, Bachera Aktar, Nadia Farnaz, Pushpita Ray, Abdul Awal, Raafat Hassan and Sharid Bin Shafique contributed equally to this work.

\section{Correct:}

† Rushdia Ahmed, Bachera Aktar and Nadia Farnaz contributed equally to this work.

† Pushpita Ray, Abdul Awal, Raafat Hassan and Sharid Bin Shafique contributed equally to this work.

\section{The original article can be found online at https://doi.org/10.1186/s13031} 020-00329-2.

* Correspondence: ahmed.rushdia@yahoo.com

${ }^{\dagger}$ Rushdia Ahmed, Bachera Aktar, Nadia Farnaz, Pushpita Ray, Abdul Awal, Raafat Hassan and Sharid Bin Shafique contributed equally to this work. 'BRAC James P Grant School of Public Health, BRAC University, 5th Floor, (Level-6), icddrb Building, 68, Shaheed Tajuddin Ahmed Sarani, Mohakhali, Dhaka 1212, Bangladesh

Full list of author information is available at the end of the article

\section{Author details}

${ }^{1}$ BRAC James P Grant School of Public Health, BRAC University, 5th Floor, (Level-6), icddrb Building, 68, Shaheed Tajuddin Ahmed Sarani, Mohakhali, Dhaka 1212, Bangladesh. ${ }^{2}$ Department of Reproductive Health Research, World Health Organization, Geneva, Switzerland. ${ }^{3}$ Health Sector Coordination Office, World Health Organization, Cox's Bazar, Bangladesh.

Published online: 30 December 2020

\section{Reference}

1. Ahmed R, Aktar B, Farnaz N, et al. Challenges and strategies in conducting sexual and reproductive health research among Rohingya refugees in Cox's bazar, Bangladesh. Confl Health. 2020;14:83 https://doi.org/10.1186/s13031020-00329-2.

Ready to submit your research? Choose BMC and benefit from

- fast, convenient online submission

- thorough peer review by experienced researchers in your field

- rapid publication on acceptance

- support for research data, including large and complex data types

- gold Open Access which fosters wider collaboration and increased citations

- maximum visibility for your research: over 100M website views per year

At BMC, research is always in progress.

Learn more biomedcentral.com/submissions

C C The Author(s). 2020 Open Access This article is licensed under a Creative Commons Attribution 4.0 International License, which permits use, sharing, adaptation, distribution and reproduction in any medium or format, as long as you give appropriate credit to the original author(s) and the source, provide a link to the Creative Commons licence, and indicate if changes were made. The images or other third party material in this article are included in the article's Creative Commons licence, unless indicated otherwise in a credit line to the material. If material is not included in the article's Creative Commons licence and your intended use is not permitted by statutory regulation or exceeds the permitted use, you will need to obtain permission directly from the copyright holder. To view a copy of this licence, visit http://creativecommons.org/licenses/by/4.0/. The Creative Commons Public Domain Dedication waiver (http://creativecommons.org/publicdomain/zero/1.0/) applies to the data made available in this article, unless otherwise stated in a credit line to the data. 